\title{
DESAIN PERENCANAAN PEMBELAJARAN BERBASIS PENDIDIKAN KARAKTER; TELAAH ATAS DEKREDITASI MORAL PESERTA DIDIK
}

\author{
Muhammad Asrori Ma'sum \\ Institut Agama Islam Bani Fattah Jombang, Indonesia \\ E-mail:perpusiaibafa@gmail.com
}

\begin{abstract}
s
Learning mechanism based on character building is structured in inter-effecting three phases of learning; planning, engagement and evaluation. Lesson plan based on character development comprised of various aspects related with the educational system elected by particular school or madrasah. Therefore, Lesson plan based on character building is employed in all school subjects. There is an interconnection among the school subjects in passing down the values that brings of character education perpetually. It shall not be halted by employment at specific classes. As necessary, school or madrasah may develop the values of character building as pastr of formal curriculum
\end{abstract}

Keywords: Lesson Plan, Interconnection of Subjects, Character Building 


\section{Pendahuluan}

Perencanaan merupakan unsur penting dan strategis yang memberikan arah dalam pelaksanaan kegiatan untuk mencapai tujuan atau sasaran yang dikehendaki. Dalam bidang pendidikan, perencanaan merupakan salah satu factor kunci efektifitas keterlaksanaan kegiatan belajar mengajar untuk mencapai tujuan pendidikan yang diharapkan bagi setiap jenjang pendidikan pada tingkat satuan pendidikan maupun pada tingkat nasional.

Namun ketika melihat realita di lapangan kesehariannya, unsure perencanaan pendidikan ${ }^{1}$ masih lebih banyak dijadikan factor pelengkap belum dijadikan sebagai 'key factor' atau penjabaran kebijakan pimpinan atau bahkan hanya dijadikan konsumtif ketika ada pemberkasan, kenaikan pangkat dan proses akreditasi, sehingga tujuan yang ditetapkan tidak tercapai secara maksimal. Salah satu penyebabnya adalah para perencana pendidikan masih kurang memahami proses dan mekanisme perencanaan dalam konteks yang lebih konprehensif. Lebih lanjut, disisi lain tuntutan tujuan pendidikan tidak hanya sempurna dibidang adminitratif; bahkan lebih dari itu, pendidikan harus mampu mengawal peserta didik memiliki kemampuan intelektual dan spiritual (pendidikan berkarakter) yang dari masa ke masa mengalami kemunduran moral (dekredasi moral).

Telaah atau kajian dalam kesempatan ini akan mencoba member penjelasan tentang posisi dan kedudukan perencanaan dalam konteks adminitrasi pendidikan dan posisinya dalam pencapaian tujuan pendidikan nasional yakni mencerdaskan kehidupan bangsa (labir batin) melalui basic pendidikan karakter.

\section{Urgensi Pendidikan Karakter dalam Pembelajaran}

Pendidikan menjadi perhatian serius masyarakat luas, ketika moralitas dipinggirkan dalam sistem berperilaku dan bersikap di tengah masyarakat akan mengakibatkan dekreditasi moral dan terpuruk tingkat intelektualitasnya, sehingga menjadikan manusia kehilangan kemanusiaannya. Maraknya aksi kekerasan, tawuran, narkoba, korupsi, pembalakan liar dan sederet gambaran dekadensi moralitas menghadapkan kepada kerinduan untuk mendesain ulang sistem

\footnotetext{
1 Perencanaan pembelajaran merupakan keseluruhan proses pemikiran dan penentuan semua aktivitas yang akan dilakukan pada masa yang akan datang dalam rangka akan mencapai tujuan sebagaimana dikutip oleh Abdul Bajid, Perencanaan Pembelajaran, (Bandung: PT. Rosda Karya, 2009), 18.
} 
pendidikan yang berbasis kepada keluhuran akhlak, tata etika dan moralitas. Antara kehidupan dan pendidikan bagaikan sebuah skema listrik paralel. Keduanya saling terkait satu sama lain. Implikasinya jika masyarakat menghendaki tersedianya kehidupan yang sejahtera, maka isi dan proses pendidikan harus diarahkan dalam pemenuhan kebutuhan tersebut.

Pendidikan Karakter dalam grand desain pendidikan adalah proses pembudayaan dan pemberdayaan nilai-nilai luhur dalam lingkungan satuan pendidikan, lingkungan keluarga dan lengkungan masyarakat ${ }^{2}$. Secara bahasa karakter berasal dari bahsa latin "character" yang berarti watak, tabiat, akhlak, atau kepribadian seseorang yang terbentuk dari hasil internalisasi berbagai kebajikan (virtues) yang diyakini dan digunakan sebagai landasan untuk cara pandang, berpikir, bersikap, dan bertindak ${ }^{3}$.

Dari pengertian diatas, jelaslah bahwa karakter merupakan kebajikan yang ditanamkan pendidik melalui internalisasi atau memasukan materi dan nilai yang mempunyai relevansi dalam membangun sistem berpikir dan berperilaku siswa.

Karakter diajarkan dengan mengenalkan, memahamkan hingga mengajak siswa sehingga pada akhirnya mereka mampu mempraktikkan dan memaknainya sebagai sesuatu yang melekat, dan menjadi tindakan perenungan (reflective action) serta mengembangkannya menjadi pusat keunggulan insani (center of human excellence). Proses pengembangan nilainilai yang menjadi landasan dari karakter itu menghendaki suatu proses yang berkelanjutan, dilakukan melalui berbagai mata pelajaran yang ada dalam kurikulum (kewarganegaraan, sejarah, geografi, ekonomi, sosiologi, antropologi, bahasa Indonesia, IPS, IPA, matematika, agama, pendidikan jasmani dan olahraga, seni, serta ketrampilan). Oleh karena itu, inilah saatnya menumbuhkan kepribadian melalui pendidikan karakter. Kemdikbud membedakan beberapa istilah yang memiliki kedekatan makna antara kepribadian dengan karakter. Adapun beberapa istilah tersebut antara lain: (a). Personality (kepribadian): penggambaran tingkah laku secara deskriptif tanpa memberi nilai (devaluative). (b) Character (karakter): penggambaran tingkah laku dengan menonjolkan nilai (benarsalah, baik-buruk) baik secara eksplisit maupun implisit. (c). Dispotition (watak): karakter yang telah lama dimiliki dan sampai sekarang belum

\footnotetext{
${ }^{2}$ Koentjaraningrat, Kebudayaan Mentalitas dan Pembangunan, (Jakarta: Gramedia, 2002), 29

${ }^{3}$ Departemen Pendidikan Nasional, Kamus Besar Bahasa Indonesia, (Jakarta: Pusat Bahasa Depdiknas, 2008), 219
} 
berubah (dengan) Temperamen (temperamen): kepribadian yang berkaitan erat dengan determinan biologik atau fisiologik, disposisi hereditas. (e). Traits (sifat): respon yang senada (sama) terhadap sekelompok stimuli yang mirip, berlangsung dalam kurun waktu yang (relatif) lama. (f). Type-attribute (ciri): mirip dengan sifat, namun dalam kelompok stimuli yang lebih terbatas. (g). Habit: kebiasaan respon yang sama cenderung berulang untuk stimulus yang sama pula ${ }^{4}$ Muara dari berbagai pengertian yang mengemuka dalam mengartikan pendidikan karakter menyiratkan pesan bahwa pendidikan karakter tidak hanya dijadikan sebagai salah satu pilar pedoman berperilaku umat manusia secara keseluruhan (way of life), namun juga mampu mendorong segenap manusia untuk konsisten melaksanakan nilai-nilai pendidikan karakter (agent of change) dimanapun ia berada.

\section{Menentukan Perencanaan Pembelajaran Berbasis Pendidikan Karakter}

Beredar anggapan bahwa sesungguhnya pendidikan karakter sudah ditanamkan semenjak dulu. Namun kenapa sekarang dihadirkan kembali dalam ranah pembelajaran? Ini tak lepas dari tuntutan dunia pendidikan modern yang mensyaratkan adanya perencanaan, proses hingga penilaian pembelajaran yang dapat diukur dengan jelas oleh siapapun dan kapanpun. Salah satu caranya adalah dengan penyedian perangkat pembelajaran berbasis pendidikan karakter. Menurut Kemdikbud, beberapa langkah yang harus dilakukan guru dalam persiapan pembelajaran, yaitu:

a) Merumuskan tujuan pembelajaran, dalam pelaksanaan KTSP diwujudkan dalam bentuk indikator. Indikator pencapaian kompetensi dikembangkan oleh sekolah, disesuaikan dengan lingkungan setempat, dan media serta lingkungan belajar yang ada di sekolah.

b) Merumuskan alat evaluasi atau asesmen, baik bentuk, cara, waktu, dan model evaluasi yang akan dilakukan. Evaluasi ini bisa berupa formatif (evaluasi untuk memperbaiki pembelajaran) maupun sumatif (evaluasi untuk melihat keberhasilan belajar siswa).

c) Memilih materi pelajaran yang esensial untuk dikuasai dan dikembangkan dalam strategi pembelajaran. Materi pelajaran yang dipilih terutama berkaitan dengan prinsip, yang berisi sejumlah konsep dan konten yang menjadi alat untuk mendidik dan

${ }^{4}$ Dirjen PMPTK Depdiknas, Monitoring dan Evaluasi Pelaksanaan Pembelajaran, (Jakarta: Depdiknas, 2009), 7-8. 
mengembangkan kemampuan siswa.

d) Berdasarkan karakterisktik materi (bahan ajar) maka guru memilih strategi pembelajaran sebagai proses pengalaman belajar siswa. Pada tahap ini guru harus menentukan metode, pendekatan, model, dan media pembelajaran, serta teknik pengelolaan kelas (laboratorium). ${ }^{5}$

Perencanaan persiapan pembelajaran tidak hanya mempertimbangkan hal-hal yang berpengaruh terhadap komponen pembelajaran seperti strategi, media dan metode yang digunakan. Namun dalam mempersiapkan pembelajaran juga harus ditimbang keadaan internal di sekitar ruang yang akan digunakan dalam kegiatan belajar mengajar. Misalnya saja tentang bagaimana kondisi sosial siswa dan orang tuanya, kesadaran untuk terus belajar. Hal ini dilakukan agar perencanaan pembelajaran yang disusun, tidak hanya dapat dicerna siswa saat berada di dalam kelas, melainkan pula siswa sudah memiliki persiapan dan modal awal untuk mempraktikkanya ketika mereka sudah kembali ke rumahnya masing-masing. Penulis buku kependidikan, Kusrini menegaskan ada beberapa faktor yang berkaitan dengan persiapan pembelajaran yakni:

1) Guru perlu menelaah analisis hari efektif dan analisis Program Pembelajaran.

Hal ini perlu dilakukan untuk mengetahui jumlah hari efektif dan hari libur tiap pekan atau tiap bulan sehingga memudahkan penyusunan program pembelajaran selama satu semester.

2) Guru perlu membuat program tahunan, program semester dan program tagihan.

Hal ini dilakukan agar keutuhan dan kesinambungan program pembelajaran atau topik pembelajaran yang akan dilaksanakan dalam dua semester tetap terjaga.

3) Guru perlu menyusun silabus. Ini dilakukan agar garis besar, ringkasan, ikhtisar, atau pokok-pokok isi atau materi pelajaran mampu mengantarkan siswa mencapai standar pembelajaran yang dituju.

4) Guru perlu menyusun rencana pelaksanaan pembelajaran. Hal ini dilakukan agar proses pelaksanaan pembelajaran terarah dan dapat berlangsung sesuai harapan.

5) Guru perlu melakukan penilaian pembelajaran. Hal ini dilakukan agar proses pembelajaran yang berlangsung dapat ditentukan

\footnotetext{
${ }^{5}$ Depdiknas, Permendiknas No. 22 Tahun 2006, (Jakarta, Depdiknas, 2009), 2
} 
keberhasilan atau kegagalannya dalam skala nilai. ${ }^{6}$

Perencanaan pembelajaran merupakan "hal baru" yang dilakukan oleh guru. Dikatakan demikian, karena sebagian guru merasa aneh dan kesulitan dalam membuat perencanaan pembelajaran. Hal ini terjadi karena guru yang bersangkutan belum memahami sepenuhnya tentang hubungan pembelajaran dengan efektifitas kegiatan belajar mengajar. Di samping itu, sebagian guru juga memiliki persepsi dan pandangan yang berbeda tentang perencanaan pembelajaran. Di satu sisi, perencanaan pembelajaran membantu guru untuk mempermudah dalam proses pelaksanaan kegiatan belajar mengajar, namun di sisi lain, penyusunan perencanaan pembelajaran yang rumit dan melelahkan menjadikan guru agak malas untuk membuatnya. Ini yang menjadikan ada sebagian guru ada yang mengusulkan agar kewajiban untuk membuat perencanaan pembelajaran dihapuskan saja. Dalam pandangan mereka, sebaiknya guru dituntut untuk mengadopsi saja perencanaan pembelajaran dengan situasi dan kondisi tempat mereka mengajar. Hal inilah yang akan memperingan beban tugas guru dalam kegiatan belajar mengajar.

\section{Peran Guru dalam Perencanaan Pembelajaran Berbasis Pendidikan karakter}

Kecenderungan guru untuk kurang terbiasa dalam membuat perencanaan pembelajaran dikarenakan rendahnya perencaan pembelajaran sebagai sesuatu yang melelahkan. Bila ditelisik, dalam menyusun perencanaan pembelajaran, terdapat beberapa hal yang harus dilakukan guru di budaya tulis menulis. Hal inilah yang menyebabkan pembuatan dalam kelas. Hal itu tersaji dalam tabel berikut ini:

Tabel 1.1: Peran Guru dalam Pembelajaran (Disdik Jombang, t.t: 6)

\begin{tabular}{|l|l|l|}
\hline \multicolumn{1}{|c|}{ Tugas } & \multicolumn{3}{|c|}{ Peran dalam Pembelajaran } \\
\hline Pertama & $\begin{array}{l}\text { Analis dan pengembang kurikulum. Pada konteks ini, } \\
\text { aktivitas yang dilakukan adalah menganalisis isi } \\
\text { kurikulum dan mengembangkannya menjadi suatu } \\
\text { perangkat yang fokus ke arah implementasi di depan } \\
\text { kelas. }\end{array}$ \\
\hline $\begin{array}{l}\text { Analis klinis potensi siswa. Pada konteks ini, aktivitas } \\
\text { yedua dingukan adalah mengidentifikasi, dan } \\
\text { mengembangkan potensi fisik dan psikologis siswa }\end{array}$ \\
\hline
\end{tabular}

${ }^{6}$ Udin Syaifudin Saúd, Perencanaan Pendidikan; Suatu Pendekatan Komprehensif, (Bandung: PT. Remaja Rosdakarya, 2007), 34 


\begin{tabular}{|l|l|}
\hline & $\begin{array}{l}\text { yang menjadi tanggungjawabnya melalui pelayanan, } \\
\text { pembimbingan, pembelajaran dan pelatihan. }\end{array}$ \\
\hline Ketiga & $\begin{array}{l}\text { Manajer kelas, dalam konteks ini, aktivitas yang } \\
\text { dilakukan adalah; merencanakan, melaksanakan dan } \\
\text { mengevaluasi pembimbingan pembelajaran dan pelatihan. }\end{array}$ \\
\hline Keempat & $\begin{array}{l}\text { Fasilitator yakni melakukan tindakan memfasilitasi } \\
\text { siswa, hal ini focus pada penyiapan perangkat dan } \\
\text { sumber-sumber belajar di sekolah atau madrasah. }\end{array}$ \\
\hline
\end{tabular}

Berdasarkan tabel di atas, peran guru begitu beragam dalam pembelajaran. Di satu sisi ia memerankan diri sebagai manajer kelas, namun di sisi lain ia bagaikan seorang dokter yang mendiagnosis beberapa keluhan siswa mengapa mereka begitu sulit mencerna pembelajaran yang diterimanya. Maka dari itu, langkah pembelajaran yang harus disusun oleh guru, dilakukan secara berurutan untuk mencapai tujuan pembelajaran. Penentuan urutan langkah pembelajaran sangat penting artinya bagi materi-materi yang memerlukan prasyarat tertentu. Selain itu, pendekatan pembelajaran yang bersifat spiral (mudah ke sukar; konkret ke abstrak; dekat ke jauh) juga memerlukan urutan pembelajaran yang terstruktur. Rumusan pernyataan dalam langkah pembelajaran minimal mengandung dua unsur yang mencerminkan pengelolaan pengalaman belajar siswa, yaitu: kegiatan siswa dan materi.

Tabel 1.2; Contoh Pernyataan pembelajaran: (Disdik Jombang, t.t: 9)
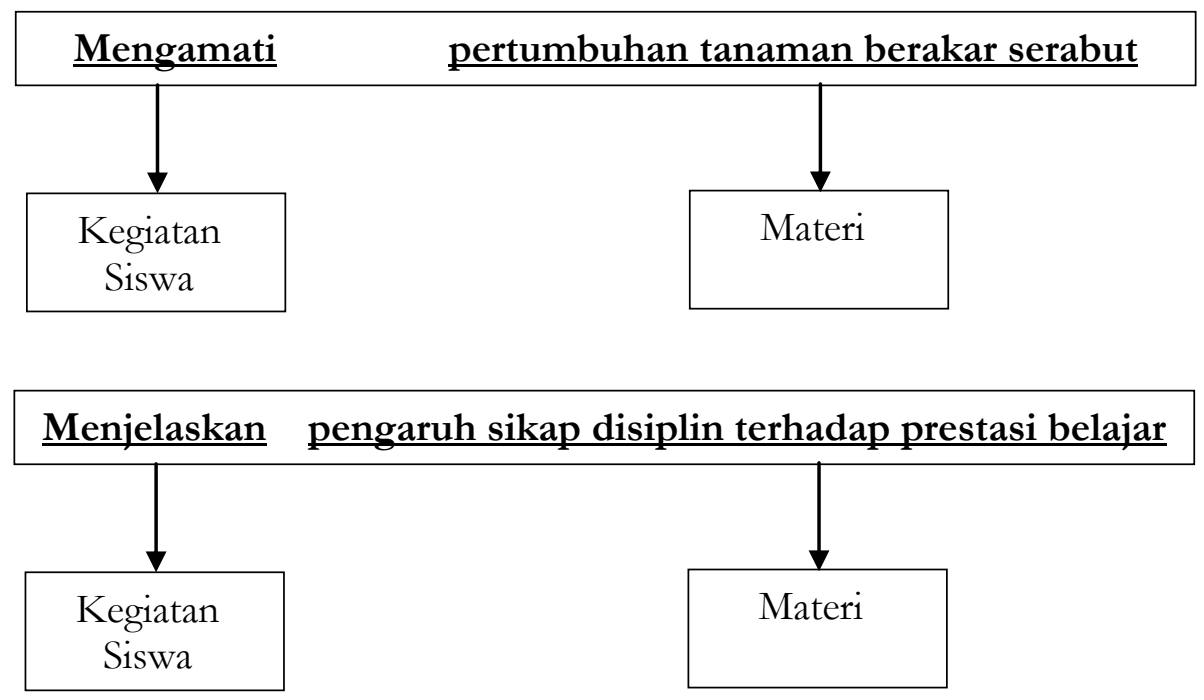
Ditetapkannya kurikulum tingkat satuan pendidikan sebagai kurikulum standar yang dipergunakan di sekolah atau madrasah memacu guru untuk lebih giat lagi dalam mengelola pembelajaran. Kini, untuk dapat mengampu mata pelajaran, guru pun dituntut mampu memperhitungkan apa yang akan diajarkannya kepada siswa. Bagaimana strategi yang digunakan hingga pada penilaian seperti apa yang mampu memotret kemampuan siswanya. Menjadi guru di era modern tak jauh bedanya dengan seorang manajer. Segala sesuatunya harus tersistem. Dengan adanya desain pembelajaran maka guru akan mendapatkan rancangan atau gambaran mengenai segala sesuatu yang dilakukannya dalam merencanakan, melaksanakan hingga menilai kegiatan belajar mengajar yang diampunya.

Pada tahap perencanaan pembelajaran, guru mulai memperhitungkan mana konsep pembelajaran yang abstrak dan sulit diterjemahkan dalam ranah praksis, serta mana pembelajaran yang dapat diperluas konteks strategi maupun materi yang ingin disampaikan kepada siswa. Perencanaan pembelajaran pendidikan karakter disusun dengan desain yang menggambarkan: Apa yang akan diajarkan kepada siswa (what), bagaimana cara pembelajaran yang dilakukan (bow), mengapa pembelajaran tersebut perlu ditanamkan (why), kapan seharusnya pembelajaran tersebut dilaksanakan (when), dimana tempat paling sesuai dengan proses pembelajaran tersebut (where), dan media apa yang paling tempat digunakan dalam pembelajaran tersebut (which). Melalui kegiatan penyusunan perencanaan pembelajaran, guru akan memiliki keunggulan dengan persiapan yang matang dan terpola dalam membangun sistem pembelajaran efektif. Perencanaan pembelajaran yang baik merupakan tahap awal dalam mendesain pembelajaran pendidikan karakter berkualitas.

Tokoh pendidikan Barat, Ernest R. Hilgard menyatakan bahwa pembelajaran dikatakannya demikian:

"Learning refers to the change in a subject's behavior or behavior potential to a given situation brought about by the subject's repeated experiences in that situation, provided that the behavior change cannot be explained on the basis of the subject's native response tendencies, maturation, or temporary states (such as fatigue, drunkness, drives, and so on). ${ }^{7}$

Dari definisi yang diberikan Hilgard tersebut, dapat dipahami bahwa

\footnotetext{
${ }^{7}$ Bower, Gordon H, dan Ernest R. Hilgrad, Theories of Learning, (New Jarsey: Prentice Hall, 1998), 11
} 
pembelajaran merupakan perubahan tingkah laku seseorang melalui pengalaman yang diulang-ulang. Hal tersebut bukanlah respon pembawaan yang dibawa seseorang, serta bukan sekedar proses kematangan yang bersifat sementara. Dengan begitu, perencanaan pembelajaran pendidikan karakter dapat dikatakan sebagai konsep pembelajaran yang akan diberikan kepada siswa berkenaan dengan materi pendidikan karakter. Lalu apa sebenarnya yang dimaksud dengan perencanaan pembelajaran pendidikan karakter yang bermutu? Paling tidak sebuah pembelajaran dikatakan memiliki nilai-nilai pendidikan karakter dan bermutu jika dalam diri siswa nampak adanya perubahan. Dari yang tidak tahu menjadi tahu, dari yang belum bisa menjadi bisa. Thontowi menyebut bahwa tujuan pembelajaran mengarah kepada pengembangan tiga hal dalam setiap diri siswa yakni pertama, pengetahuan (knowledge); Perubahan yang diharapkan adalah dari tidak mengetahui menjadi mengetahui, dari tidak mengerti menjadi mengerti, dan sebagainya. Kedua, keterampilan (skill); Perubahan yang diharapkan adalah dari tidak bisa membuat, melakukan, membentuk dan sebagainya berubah bisa membuat, melakukan, membentuk sesuatu, dan sebagainya. Ketiga, sikap (attitude); Perubahan yang diharapkan adalah dari sikap negatif menjadi sikap positif, dari sikap salah menjadi sikap baik dan sebagainya. ${ }^{8} \quad$ Pengetahuan, keterampilan dan sikap merupakan komponen utama dalam membangun manusia berkarakter. Untuk itu, ketiga domain dalam pembelajaran ini tidak boleh tertinggal,emuanya saling terkait satu sama lain.

\section{Pemetaaan Nilai-Nilai Pendidikan Karakter Dalam Perencanaan Pembelajaran}

Pemupukan pengetahuan, keterampilan dan sikap sudah semestinya dilakukan secara terorganisir dan disesuaikan dengan keadaan di masing-masing sekolah atau madrasah. Inilah alasan utama mengapa pendidikan karakter perlu diintegrasikan dalam seluruh aspek pembelajaran. Semua mata pelajaran mengusung pendidikan karakter sebagai salah satu subtansi pengetahuan dan nilai yang ingin ditanamkan kepada siswa. Berikut disajikan nilai-nilai pendidikan karakter dalam setiap mata pelajaran sebagaimana dilansir oleh Kemdikbud berikut ini:

\section{Tabel 1.3: Nilai-Nilai Pendidikan Karakter dalam Mata Pelajaran} (Kemdiknas, 2010: 11-12)

\footnotetext{
${ }^{8}$ Ahmad Thantowi, Psikologi Pendidikan, (Bandung: Angkasa, t.t.), 100
} 


\begin{tabular}{|c|c|c|}
\hline No & Mata Pelajaran & Nilai Utama \\
\hline 1 & $\begin{array}{l}\text { Pendidikan } \\
\text { Agama }\end{array}$ & $\begin{array}{l}\text { Religius, jujur, cerdas, tangguh, peduli, } \\
\text { demokratis, santun, disiplin, bertanggung jawab, } \\
\text { cinta ilmu, ingin tahu, percaya diri, menghargai } \\
\text { keberagaman, patuh pada aturan sosial, bergaya } \\
\text { hidup sehat, sadar akan hak dan kewajiban, kerja } \\
\text { keras }\end{array}$ \\
\hline 2 & Pkn & $\begin{array}{l}\text { Religius, jujur, cerdas, tangguh, peduli, } \\
\text { demokratis, nasionalis, patuh pada aturan sosial, } \\
\text { menghargai keberagaman, sadar akan hak dan } \\
\text { kewajiban diri dan orang lain }\end{array}$ \\
\hline 3 & $\begin{array}{l}\text { Bahasa } \\
\text { Indonesia }\end{array}$ & $\begin{array}{l}\text { Religius, jujur, cerdas, tangguh, peduli, } \\
\text { demokratis, berpikir logis, kritis, kreatif dan } \\
\text { inovatif, percaya diri, bertanggung jawab, ingin } \\
\text { tahu, santun, nasionalis }\end{array}$ \\
\hline 4 & Matematika & $\begin{array}{l}\text { Religius, jujur, cerdas, tangguh, peduli, } \\
\text { demokratis, berpikir logis, kritis, kerja keras, } \\
\text { ingin tahu, mandiri, percaya diri }\end{array}$ \\
\hline 5 & IPS & $\begin{array}{l}\text { Religius, jujur, cerdas, tangguh, peduli, } \\
\text { demokratis, nasionalis, menghargai keberagaman, } \\
\text { berpikir logis, kritis, kreatif, dan inovatif, peduli } \\
\text { sosial dan lingkungan, berjiwa wirausaha, kerja } \\
\text { keras }\end{array}$ \\
\hline 6 & IPA & $\begin{array}{l}\text { Religius, jujur, cerdas, tangguh, peduli, demokratis, } \\
\text { ingin tahu, berpikir logis, kritis, kreatif, dan } \\
\text { inovatif, jujur, bergaya hidup sehat, percaya } \\
\text { diri, menghargai keberagaman, disiplin, mandiri, } \\
\text { bertanggung jawab, cinta ilmu. }\end{array}$ \\
\hline 7 & Bahasa Inggris & $\begin{array}{l}\text { Religius, jujur, cerdas, tangguh, peduli, } \\
\text { demokratis, menghargai keberagaman, santun, } \\
\text { percaya diri, mandiri, bekerjasama, patuh pada } \\
\text { aturan social }\end{array}$ \\
\hline 8 & Seni Budaya & $\begin{array}{l}\text { Religius, jujur, cerdas, tangguh, peduli, } \\
\text { demokratis, menghargai keberagaman, nasionalis, } \\
\text { dan menghargai karya orang lain, ingin tahu, } \\
\text { disiplin }\end{array}$ \\
\hline 9 & Penjasorkes & $\begin{array}{l}\text { Religius, jujur, cerdas, tangguh, peduli, } \\
\text { demokratis, bergaya hidup sehat, kerja keras, } \\
\text { disiplin, percaya diri, mandiri, menghargai karya }\end{array}$ \\
\hline
\end{tabular}




\begin{tabular}{|l|l|l|}
\hline & & dan prestasi orang lain \\
\hline \multirow{3}{*}{10} & \multirow{2}{*}{$\begin{array}{l}\text { Teligius, jujur, cerdas, tangguh, peduli, } \\
\text { Kemokratis, berpikir logis, kritis, kreatif, dan } \\
\text { Keterampilan } \\
\text { inovatif, mandiri, bertanggungjawab, dan } \\
\text { menghargai karya orang lain }\end{array}$} \\
\hline 11 & Muatan Lokal & $\begin{array}{l}\text { Religius, jujur, cerdas, tangguh, peduli, } \\
\text { demokratis, menghargai keberagaman, menghargai } \\
\text { karya orang lain, nasionalis }\end{array}$ \\
\hline
\end{tabular}

Pemetaan nilai-nilai pendidikan karakter dalam mata pelajaran merupakan kerangka kerja konseptual dalam membantu guru merencanakan sekaligus melaksanakan kegiatan belajar mengajar yang berbasis pendidikan karakter. Banyak alasan yang mengemuka untuk menjawab problem tersebut: pertama, dikatakan bahwa jam pelajaran pendidikan karakter hanya terselip dalam semua pembelajaran. Hal ini menyebabkan penanaman pengetahuan dan nilai (transfer of knowledge and values) yang diberikan menjadi kurang maksimal. Kedua, guru terlalu sibuk untuk membuat desain penilaian yang bersifat kognitif. Demikian pula dengan siswanya yang termotivasi mengikuti mata pelajara berbasis pendidikan karakter, hanya untuk sekedar mendapat nilai baik di rapor. Ketiga, pembelajaran pendidikan karakter tidak membekas dalam kehidupan di sekolah apalagi masyarakat karena pembelajarannya tidak dapat menggugah siswa untuk menerapkannya.

Meski terkendala waktu pertemuan yang sempit, bukan berarti pendidikan karakter hanya menjadi "penghias, pelengkap, dan penderita" dari mapel yang ada. Justru dengan keadaan demikian, pendidikan karakter harus mampu mendarah daging di kehidupan sekolah dan diwujudkan tidak hanya dari segi pengetahuan an sich, tetapi juga menjadi budaya keseharian sekolah. Untuk itulah, aspek terpenting dari pembelajaran pendidikan karakter tidak terletak dari materi pelajaran yang disajikan. Namun terpusat pada sisi implementasi dan keteladanan. Sebab pendidikan karakter sesungguhnya adalah materi dan nilai dari pembelajaran moralitas dan spiritualitas yang terus berkembang. Untuk itu, pendidikan karakter yang ada di sekolah atau madrasah merupakan akar dalam memberikan pembekalan nilai-nilai luhur dalam bermasyarakat dan simbolisasi budaya religius dimanapun seseorang tersebut berada. Dengan kata lain, pendidikan karakter seyogyanya tidak hanya menjadi refleksi dari pemahaman hidup agamis di dunia namun juga berarti menjadi cerminan kepribadian siswa dan guru dalam menjalani hidup dalam dua kehidupan (dunia dan 
akhirat).

Fokus pembelajaran pendidikan karakter yang masih tersandera pada aspek akademik belaka, perlu dibebaskan. Meski sebagian guru mengetahui bahwa bila pendidikan karakter hanya diajarkan dengan menitikberatkan pada aspek kognitif, namun kenyataannya memang sebagian besar penilaian pembelajaran ini juga lebih mengkedepankan penilaian sisi itu. Siswa pun hanya termotivasi mempelajari pendidikan karakter untuk sekedar selamat dan prestasi di atas kertas rapor atau lembar hasil belajar siswa. Namun kurang begitu tertarik dan tertantang untuk menjelmakannya dalam kehidupan pribadinya, antar teman sepergaulan, orang tua apalagi masyarakat.

Adanya perubahan orientasi penilaian pendidikan karakter merupakan keniscayaan. Sudah saatnya titik konsentrasi pendidikan karakter tertuju kepada penilaian afektif. Sebab bagaimanapun untuk anak sekolah, tingkat kognisi pendidikan karakter yang diajarkan tidak sedalam siswa madrasah maupun pesantren. Jadikan saja bahwa penilaian afektif sangat mempengaruhi terhadap kenaikan kelas siswa melebihi dari balutan angka yang terkadang hanya menggambarkan sisi pengamalan pendidikan karakter di permukaan namun tidak akurat bila dijadikan penilaian yang sesungguhnya.

Ini yang akan "memaksa" siswa untuk menyerap pendidikan karakter sebagai jalan kehidupan di kehidupan sekolah daripada menargetkan mendapatkan nilai "10" di kelas. Apalagi banyak fakta yang memperlihatkan setiap ganti tahun ajaran baru, sejumlah siswa mengalami lupa atau sulit mengingat kembali materi dan nilai-nilai pendidikan karakter yang diberikan. Hal ini dikarenakan karena daya serap siswa terhadap materi dan nilai-nilai pendidikan karakter masih pada short term memory (memori jangka pendek). Adanya kecenderungan ini bisa jadi disebabkan : pertama, gaya pengajaran yang diberikan guru terlihat kurang menginspirasi siswa. Kedua, siswa tidak termotivasi atau mendapatkan impian untuk menerapkan pendidikan karakter di kehidupannya sehingga mapel pendidikan karakter tidak membekas dalam kehidupannya. Agar pendidikan karakter dapat teringat dan terinspirasi selalu dalam kehidupan siswa (long term memory), mapel ini harus disajikan dengan contoh yang ada sangkut pautnya dengan kehidupan siswa. Penyajian pendidikan karakter yang banyak bersentuhan dengan persoalan yang menukik dengan keseharian siswa akan menjadikan siswa tidak hanya sekedar mengikuti kegiatan belajar mengajar tersebut, tetapi juga karena mereka merasa butuh. Persoalan kehidupan siswa yang dapat diangkat guru untuk disajikan ke dalam 
pembelajaran pendidikan karakter antara lain: narkoba, pacaran, jati diri remaja, jihad dalam belajar, pola berbakti kepada orang tua dan sebagainya.

Titik tolakan inilah yang akan mengubah pola pandang siswa dalam memahami pendidikan karakter, dari sekedar materi pembelajaran yang penuh dengan normatif untuk mengembangkan menjadi pendidikan ilmu kehidupan di dunia dan di akhirat. Inilah sebuah langkah mendasar (backbone) dalam membentuk siswa berkarakter melalui pembumian nilai-nilai pendidikan karakter dari kehidupan paling terdekat siswa.

\section{Aktivitas Guru dalam Penyusunan Perencanaan Pembelajaran}

Kesuksesan suatu lembaga pendidikan dipengaruhi oleh kualitas gurunya. Jika lembaga pendidikan tersebut dipenuhi dengan guru yang berkualitas, maka output yang dihasilkan pun akan lebih terjamin dan maksimal. Begitu pula sebaliknya, jika lembaga pendidikan tersebut banyak dihuni oleh guru yang kualitasnya jauh dari unsur kemutuan, maka output yang dikeluarkannya menjadi kurang maksimal dan bisa jadi malah tidak bisa menyamai standar pembelajaran yang diharapkan.

Terus tumbuhnya kesadaran baru dalam menyajikan mata pelajaran yang menyentuh semua aspek siswa menjadi dorongan bagi guru untuk terus meningkatkan kemampuan mengajarnya. Seiring dengan itu, benihbenih kesadaran guru untuk terus memperbaiki kualitas pengajarannya pun terus menggeliat. Ini menjadi semacam modal dasar dalam merancang pembelajaran dan pendidikan karakter yang multi makna.

Ketuntasan dan keefektifan pembelajaran tidak hanya ditentukan strategi dan materi yang diajarkan. Melainkan pula dipengaruhi juga oleh faktor guru. Sebuah kaidah pembelajaran dari Arab menyatakan al-țrîqat ahammu min al-mâddah, wa lâkin al-mudarris ahammu min al-tarîqah. Kaidah tersebut mengandung pengertian bahwa metode (pembelajaran) lebih penting daripada materi (belajar), akan tetapi eksistensi guru (dalam proses belajar mengajar) jauh lebih penting daripada metode pembelajaran itu sendiri. ${ }^{9}$ Untuk itulah, mengampu pembelajaran dan pendidikan karakter tidak boleh diajarkan kepada guru amatir. Dalam bahasan Berkson dan Wettersten, proses penanaman pendidikan karakter tidak hanya bertumpu kepada sekedar pemindahan (transfer) materimateri, tetapi transformasi atau pengubahan (transformation); baik itu

\footnotetext{
${ }_{9}^{9}$ Malik Fajar, Holistika Pemikiran Pendidikan, (Jakarta,: PT. Raja Grafindo Persada, 2005), 188
} 
pengetahuan, keterampilan, maupun nilai. ${ }^{10}$ Menanamkan nilai-nilai pendidikan karakter memerlukan sosok dengan kecakapan keilmuan yang kompleks. Apalagi, pendidikan karakter sesungguhnya mempunyai kedekatan dengan kehidupan sehari-hari siswa. Proses interaksi antara orang tua dan anak, proses jual beli di toko kelontong dekat rumah, sejarah candi-candi di sekitar tempat tinggalnya merupakan contoh kehidupan yang didalamnya penuh dengan muatan pendidikan karakter. Oleh karena itu, dalam melaksanakan kegiatan pembelajaran, apa yang semua yang terjadi, tergelar dan berkembang di masyarakat dan lingkungan sekitar serta lingkungan alam semesta dijadikan sumber belajar, contoh dan teladan.

\section{Pengembangan Perencanaan Pembelajaran}

Pemberian materi pembelajaran memang penting untuk memberi wawasan dan pengetahuan yang luas mengenai nilai-nilai pribadi dan sosial dalam pendidikan karakter kepada siswa. Pengetahuan di sini mengacu sebagaimana hierarki yang dibuat oleh Bloom. Sekalipun demikian, maknanya tidak sepenuhnya tepat sebab dalam istilah tersebut termasuk pula pengetahuan faktual disamping pengetahuan hafalan atau untuk diingat seperti pengertian, jenis-jeis, definisi, istilah, nama-nama tokoh yang menjadi panutan, dalam pendidikan karakter dan sebagainya. Dilihat dari segi proses belajar, istilah-istilah tersebut memang perlu dihafal dan diingat agar dapat dikuasainya sebagai dasar bagi pengetahuan atau pemahaman konsep-konsep dasar dalam mempelajari pendidikan karakter. ${ }^{11}$

Tipe hasil balajar yang lebih tinggi dari pada pengetahuan adalah pemahaman. Misalnya menjelaskan manfaat yang dapat dirasakan dengan menerapkan nilai-nilai yang terkandung dalam pendidikan karakter, memberi contoh dari penerapan nilai-nilai pendidikan karakter, menggunakan sikap peduli lingkungan dan tanggung jawab dalam memelihara kondisi taman di sekolah atau madrasah. Dalam taksonomi Bloom, kesanggupan memahami setingkat lebih tinggi dari pada pengetahuan. Namun, tidaklah berarti bahwa pengetahuan tidak perlu ditanyakan. Sebab, untuk dapat memahami, perlu terlebih dahulu mengetahui atau mengenal.

Tingkat yang lebih tinggi dari pemahaman adalah aplikasi. Kegiatan

10 William Berson, Psikologi Belajar dan Filsafat Ilmu Karl Popper, terj. Ali Noer Zaman, (Yogyakarta: Qalam, 2003), V

${ }^{11}$ Depdiknas, Permendiknas No. 22 Tabun 2006, (Jakarta: Depdiknas, 2009), 12 
ini merupakan penggunaan abstraksi pada situasi kongkret atau situasi khusus. Abstraksi tersebut mungkin berupa ide, teori, generalisasi dan pedoman atau petunjuk teknis pelaksanaan nilai-nilai pendidikan karakter. Menerapkan abstraksi ke da-lam situasi baru disebut aplikasi. Aplikasi yang berulangkali dilakukan pada situasi lama akan beralih menjadi pengetahuan hafalan atau keterampilan. Suatu situasi akan tetap dilihat sebagai situasi baru bila terjadi proses pemecahan masalah. Dalam proses perencanaan pembelajaran pendidikan karakter, guru dapat mengetengahkan sebuah problem baru di tengah siswa, misalnya saja masalah kebersihan ruang kelas. Problem tersebut lebih didasarkan atas realitas yang ada di sekitar siswa. Dari situ, siswa didorong oleh guru (setelah proses pemberian materi dan pemahamannya) menerapkan nilai-nilai dasar pendidikan karakter seperti peduli lingkungan dan sikap tanggung jawab, pada permasalahan kebersihan kelas mereka. ${ }^{12}$

Melangkah kepada tahap pembelajaran yang lebih tinggi adalah analisis. Dalam tahapan tersebut, siswa diperkenankan oleh guru untuk berusaha memilah suatu integritas dari rangkaian proses pembelajaran pendidikan karakter menjadi unsur-unsur atau bagianbagian sehingga jelas hierarkinya dan susunannya. Analisis merupakan suatu kecakapan yang kompleks, yang memanfaatkan kecakapan dari ketiga tipe hasil belajar sebelumnya. Dengan kemampuan analisis diharapkan siswa mempunyai pemahaman yang komprehensif tentang materi pendidikan karakter dan dapat memilah atau memecahnya menjadi bagian-bagian yang terpadu baik dalam hal prosesnya, cara bekerjanya, maupun dalam hal sistematikanya. Bila kecakapan analisis telah dikuasai siswa maka siswa akan dapat mengaplikasikannya pada situasi baru secara kreatif.

Hal inilah yang akan mempengaruhi siswa untuk terus mengembangkan pola berpikir yang rasional. Ketika siswa sudah mampu berpikir rasional, ia akan beranjak kepada bernalar ilmiah yang menjadi struktur dasar pemikiran keilmuan modern.

Pada tahap tingkatan pembelajaran berikutnya, siswa didorong oleh guru untuk melakukan penyatuan unsur-unsur materi pembelajaran pendidikan karaker ke dalam bentuk menyeluruh disebut sintesis. Proses pembelajaran ini merupakan rangkaian dari pelatihan siswa untuk berpikir berdasar pengetahuan hafalan, berpikir pemahaman, berpikir aplikasi, dan berpikir analisis menuju cara berpikir devergen. Dalam

12 Depdiknas, Permendiknas No. 22 Tabun 2006, (Jakarta: Depdiknas, 2009), 13-14 
berpikir divergen pemecahan masalah atau jawabannya belum dapat dipastikan. Dalam proses ini, guru mulai mengenalkan berbagai macam cara berpikir kreatif kepada siswa dikenalkan. Siswa mulai dilatih berpikir kreatif dengan teknik menemukan atau menciptakan sesuatu dari persoalan, problem atau solusi ketika guru memberikan materi pendidikan karakter. Dengan kemampuan sintesis, siswa dimungkinkan untuk menemukan hubungan kausal, urutan tertentu, astraksi dari suatu fenomena yang mengandung muatan pendidikan karakter.

\section{Kesimpulan}

Perencanaan pembelajaran bermanfaat dalam menetapkan kecermatan maupun kesesuaian segala strategi maupun materi pembelajaran pendidikan karakter. Ini dilakukan agar prinsip-prinsip pembelajaran pendidikan karakter yang telah tersusun dalam lembar kerja (worksheet) guru dapat dipastikan tersaji secara menyeluruh, tanpa ada tahapan pembelajaran yang ditinggalkan. Hal tersebut merupakan bagian dalam membangun sistem pembelajaran yang analitis, visioner dan kontekstual.

Kegiatan perencanaan pembelajaran merupakan langkah awal dalam menyusun kegiatan belajar mengajar yang efektif. Sebab dengan adanya perencanaan akan diketahui arah, orientasi, kemampuan yang ingin ditanamkan hingga strategi yang digunakan. Merancang perencanaan pembelajaran akan mengantarkan guru memahami gambaran proses pembelajaran yang diampunya. Ini dilakukan agar guru memiliki persiapan yang matang dalam menghadapi proses dinamika yang akan terjadi saat guru tersebut melakukan proses pembelajaran kepada siswanya. 


\section{Daftar Pustaka}

Depdiknas. Panduan Pengembangan Mata Pelajaran Muatan Lokal. Jakarta: Depdiknas, 2007.

Depdiknas. Permendiknas No. 22 Tahun 2006. Jakarta: Depdiknas, 2006.

Dinas Pendidikan Kabupaten Jombang UPTD Balai Pelatihan Guru. Modul Peningkatan Mutu Tenaga Kependidikan. Jombang: Diknas Jatim, t.t.

Dirjen PMPTK Depdiknas. Monitoring dan Evaluasi Pelaksanaan Pembelajaran. Jakarta: Depdiknas, 2008.

Fadjar, Malik. Holistika Pemikiran Pendidikan. Jakarta: PT. Raja Grafindo Persada, 2005.

Gordon H. Bower dan Ernest R. Hilgard. Theories of Learning. New Jersey: Prentice Hall Inc, 1998. 4 Edition.

Kemdiknas. Pendidikan Karakter Terintegrasi dalam Pembelajaran di Sekolah Menengah Pertama. Jakarta: Kemdiknas, 2010.

Thonthowi, Ahmad. Psikologi Pendidikan. Bandung: Angkasa, t.t.

Udin, Syaifudin. Perencanaan Pendidikan; Suatu Pendekatan Komprehensif. Bandung: PT. Remaja Rosdakarya, 2007.

William Berkson dan John Wettersten. Psikologi Belajar dan Filsafat Ilmu Karl Popper. terj. Ali Noer Zaman. Yogyakarta: Qalam, 2003. 